\title{
ELECTROLYTES AND ITS ADDITIVES USED IN ALUMINUM REDUCTION CELL: A REVIEW
}

\author{
Sai Krishna Padamata ${ }^{a}$, Andrey S. Yasinskiy ${ }^{b}$, Petr V. Polyakov \\ School of Non-Ferrous Metals and Materials Science, Siberian Federal University, Krasnoyarsk \\ 660025, Russia.

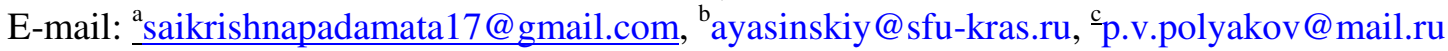

\begin{abstract}
The electrolyte is considered to play the role of blood in an aluminum reduction cell and performs several vital functions as the charge transfer, the mass dissolution and transfer, the electrode products separation and the electrical work dissipation. The proper performance of listed functions is completely determined by the physical and chemical properties, which namely are the electrical conductivity, the viscosity, the vapor pressure, the liquidus and solidus temperatures, the density, the surface tension, the solubility and the dissolution rate of oxides, aluminum, carbon and the various connections and by operating conditions, which namely are the temperature, the current density, the anode-cathode distance, etc. The electrolyte affects the current efficiency and the cell voltage, which determines the specific energy consumption and the total cost of aluminum. This is the reason why different electrolytes and additives have been in the spotlight of the researchers and the enterprises for decades. This article presents the brief information about the influence of additives in the cell utilizing traditionally used sodium cryolite and different low-temperature electrolytes on physical-chemical properties and concentrates on the latest works which have not been included in widely known textbooks. The article also contains new experimental results obtained by the authors and devoted to the effective electrical conductivity of suspended unconventional electrolytes.
\end{abstract}

Keywords: electrolyte properties, low-temperature electrolytes, cryolite melt, suspension electrolyte, Additives.

\section{$1 \quad$ Introduction}

Aluminum is one of the highly smelted metals in the world as bauxite being one of the most abundant ore in the earth's crust from which alumina is extracted. Earlier, almost 70 million ton of aluminum is been smelted as it is used in different ways like in construction, fabrication of auto-parts and aircrafts and so on because of its light density and high strength at the same time [1]. Hall-Heroult's process, have been in use for the production of aluminum for over 120 years and the process is continued to be used until date. A typical Hall-Heroult Cell and the concept of alternatively designed cell with vertical electrodes proposed by the authors of the current paper, which can be used with suspension electrolytes and has the detailed description in [2], are shown in figure 1.
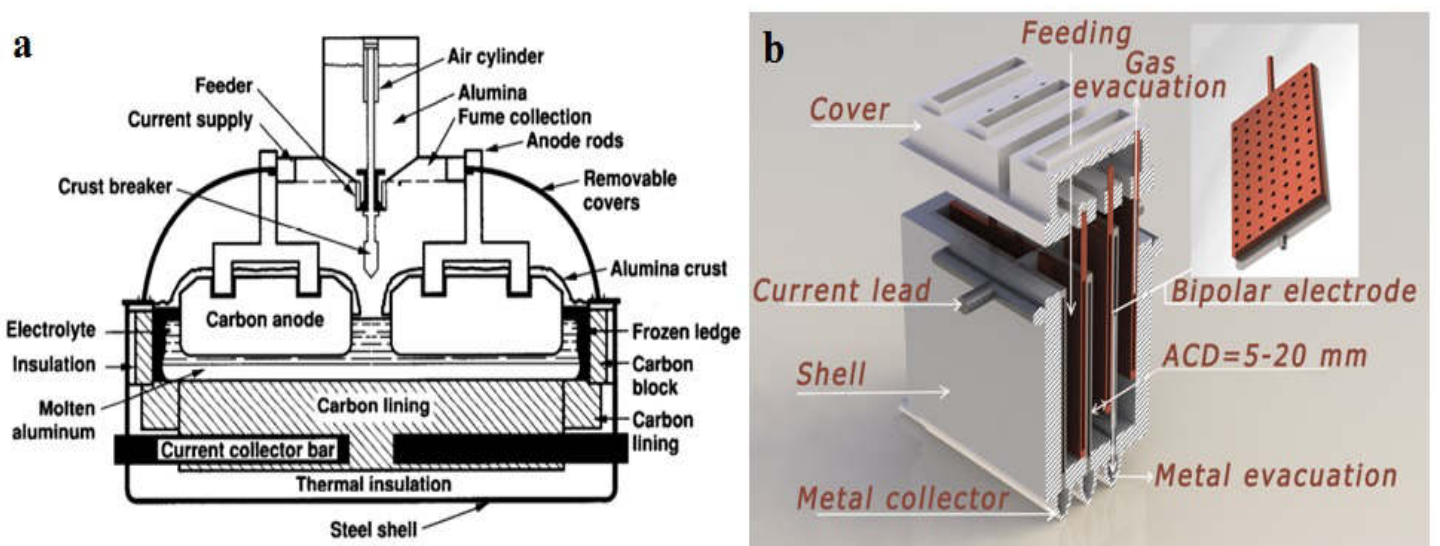

Figure 1 - Schematic diagram of a: Hall-Heroult Cell [3]; b: Novel design cell 
In the Hall-Heroult process, carbon anode and aluminum cathode are used and the alumina fed to the cell is dissolved in the fluoride bath of molten cryolite-based electrolyte at $960{ }^{\circ} \mathrm{C}$. The main reaction occurred in this process is

$$
2 \mathrm{Al}_{2} \mathrm{O}_{3 \text { (solution) }}+3 \mathrm{C}_{(\mathrm{s})}=4 \mathrm{Al}(\mathrm{l})+3 \mathrm{CO}_{2(\mathrm{~g})}
$$

In the reaction (1), the dissolution of alumina results in the formation of oxyfluoroaluminates while using sodium cryolite, where its structure depends on the electrolyte composition. The oxyfluoroaluminates formed are $\mathrm{AlOF}_{\mathrm{x}}^{1-\mathrm{x}}, \mathrm{Al}_{2} \mathrm{OF}_{\mathrm{x}}^{4-\mathrm{x}}, \mathrm{Al}_{2} \mathrm{O}_{2} \mathrm{~F}_{\mathrm{x}}^{2-\mathrm{x}}, \mathrm{Al}_{4} \mathrm{OF}_{8}$ and $\mathrm{Al}_{4} \mathrm{OF}_{10}$ out of which $\mathrm{AlOF}_{2}^{-}, \mathrm{Al}_{2} \mathrm{OF}_{6}^{2-}$ and $\mathrm{Al}_{2} \mathrm{O}_{2} \mathrm{~F}_{4}^{2-}$ are the most stable and involved structures in the electrolysis process [4], [5]. Their presence in the cryolite mixture increases the electrical resistance, viscosity of the liquid and decreases the vapor pressure of the melt. The formation of the anionic fluro-aluminates in the cryolite melt depends on the cryolite ratio (CR) and concentration of alumina dissolved. The complex ionic form such as $\mathrm{AlF}_{4}^{-}, \mathrm{AlF}_{5}^{2-}, \mathrm{AlF}_{6}^{-3}, \mathrm{Al}_{2} \mathrm{O}_{2} \mathrm{~F}_{4}^{2-}$ and $\mathrm{Al}_{2} \mathrm{OF}_{6}^{2-}$ are formed at $1<\mathrm{CR}<3$ and $\mathrm{Al}_{3} \mathrm{O}_{4} \mathrm{~F}_{4}^{3-}$ complex ion is only formed at $3<\mathrm{CR}<4$ in alumina saturated melts [6], [7], [8]. The structural properties of solid cryolite were widely studied by Kirik et al. [9] and Samoilo et al. [10].

The bath is a subsystem of an aluminum reduction cell and is being considered as the dissipative structure. It performs the following basic functions:

- Charge transfer;

- Substance dissolution and transfer;

- Cathodic and anodic products separation;

- Electrical work dissipation, maintaining the enthalpy of substance at the high temperature and providing required heat loss into the environment.

Bath composition and temperature highly affect its properties and consequently the technical and economic indicators of the electrolysis.

The electrolyte used presently in the smelters around the world is based on sodium cryolite system and its operating temperature is around $960{ }^{\circ} \mathrm{C}$. Many other reactions occur besides reaction (1) in the cell. Alumina fed in the cell contains the impurities of $\mathrm{Li}$ and $\mathrm{K}$, which changes the composition of the melt affecting the current efficiency and the operating conditions of the cell. As the operating temperature of the cell with electrolyte based on sodium cryolite is high, it results in a quick corrosion of the cell parts reducing the lifetime of a cell.

The inert (non-consumable or carbonless) anodes [11] [12] are highly desirable in aluminum production. Sodium cryolite in the electrolysis process eliminates the use of most of the metals which are highly (!confusing word) towards high-temperature melts. Using low-temperature electrolytes gives the scope to conduct tests on the materials which can be operated at temperatures around $750-800{ }^{\circ} \mathrm{C}$ [13]. Potassium cryolite $\left(\mathrm{KF}-\mathrm{AlF}_{3}\right)$ can be operated between $680-800{ }^{\circ} \mathrm{C}$ [14], [15] . The solubility of alumina increases by $30 \%$ while using potassium cryolite than compared to sodium cryolite but the electrical conductivity of the potassium cryolite is low compared to that of sodium cryolite. Many experiments were conducted to characterize the $\mathrm{KF}-\mathrm{NaF}-\mathrm{AlF}_{3}$ melt which can be used as lowtemperature electrolyte.

In the year 1971, scientists from Alcoa patented a process by which aluminum can be extracted from $\mathrm{AlCl}_{3}$ (replacement of alumina as a feed) by using molten alkali metal chloride or alkaline earth metal chlorides as electrolyte at $730{ }^{\circ} \mathrm{C}$ but the main problem was the unavailability of pure $\mathrm{AlCl}_{3}$. In 1979, it was claimed by Alcoa scientists that the $\mathrm{AlCl}_{3}-\mathrm{LiCl}_{3}$ molten system can be used as a lowtemperature electrolyte at $700^{\circ} \mathrm{C}$ as discussed in the patents [16]-[19]. Currently, several researchers are studying the behavior of the suspension electrolyte with the operational temperature between 700 and $800{ }^{\circ} \mathrm{C}$. The suspension particles (being alumina) can be added up to 30 vol.\% fraction in the melt, which drastically reduces the electrical conductivity, and to compromise this issue, the anode-cathode distance have to be reduced. The main purpose of alumina suspension particles in the melt is to reduce the corrosion, which damages the cell parts, the anodes, and to slow down the mass transfer of corrosion products into aluminum. By using suspension electrolytes, the use of inert anodes can be encouraged. Minh et al. [20] discussed the chemical fundamentals and the properties such as electrical conductivity, operation temperature, vapor pressure, corrosiveness, current efficiency, diffusivity, viscosity and electrode kinetics of molten salt electrolytes. 
The bath composition is generally optimized to minimize specific energy consumption which can be expressed by the equation:

$$
W=f_{1}\left(\frac{E_{p}+f_{2}(i \rho l)}{\eta}\right)
$$

where, $W$ is the Specific energy consumption, $E_{p}$ is the EMF, $i$ is the current density, $\rho$ is the specific resistance, $l$ is the inter-electrode distance and $\eta$ is the current efficiency.

By minimizing the specific resistance of the electrolyte, the specific energy consumption of the cell can be reduced.

\section{Electrolytes and influence on its properties by the additives}

\subsection{NaF-AlF 3 electrolyte and its additives}

In the Hall-Heroult process, the bath is based on sodium cryolite with operating temperature $955-970^{\circ} \mathrm{C}$ which is said to be the traditional industrial electrolyte. There are many factors that influence the performance of the cell. Inclusion of additive in the electrolyte changes the electrical conductivity of the system drastically [21]. It is well known that the industries desire to use electrolytes with more acidic content (Cryolite ratio (CR) between 2.12 and 2.30). An increase in $\mathrm{AlF}_{3}$ content in the molten cryolite increases the acidic nature of the electrolyte. Decrease in CR ( NaF mol\% / $\mathrm{AlF}_{3} \mathrm{~mol} \%$ ) decreases the solubility of alumina in the melt [22]. Maintenance of the frozen side ledge becomes extremely difficult at low CR's.

J. Wang et al. [23] discussed the behavior of the sodium cryolite melt with high $\mathrm{Li}^{+}$and $\mathrm{K}^{+}$ions concentration. The presence of the $\mathrm{Li}^{+}$and $\mathrm{K}^{+}$ions in the electrolyte is due to the use of impure alumina with high content of $\mathrm{Li}_{2} \mathrm{O}$ and $\mathrm{K}_{2} \mathrm{O}$. The electrolyte with high content of $\mathrm{LiF}$ and $\mathrm{KF}$ provides slightly less current efficiency compared to the pure sodium cryolite melt. However the electrical conductivity of the electrolyte containing $\mathrm{Li}^{+}$is higher than that of the regular electrolyte which can favor energy saving. Influence of $\mathrm{CaF}_{2}$ addition on the electrical conductivity of the sodium cryolite was tested in [24]. It was observed that with the increase in the $\mathrm{CaF}_{2}$ concentration, the electrical conductivity decreases as shown in figure 2 .

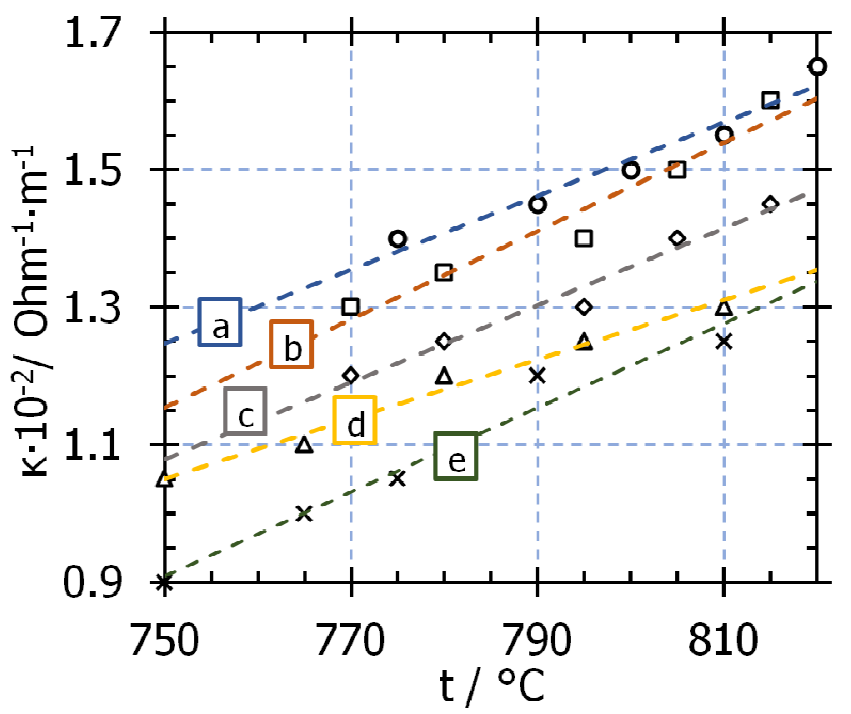

Figure 2 - Electrical conductivity of the $\left(\mathrm{NaF}-\mathrm{AlF}_{3}\right)-\mathrm{CaF}_{2}$ mixture with $(\mathrm{CR}=1.5)$ depending on the $\mathrm{CaF}_{2}$ (mol. \%) concentration: a-2.3, b-4.6, c-7.8, d-9.4, e-11 [24]

Dewing et al. [25] conducted tests to find the influence of additives in the electrolyte on the current efficiency of the cell. Inclusion of $\mathrm{LiF}$ leads to an increase in the current efficiency. It was also observed that the addition of $\mathrm{CaF}_{2}$ in electrolyte does not have direct effect on the current efficiency of 
the cell but it affects the superheat which influences the current efficiency. An equation (3) was obtained to determine the current efficiency influenced by the additives and is stated below.

$$
\lg \left(\Delta \eta_{i}\right)=0.0095 \cdot \Delta T-0.019 \cdot C_{A l F_{3}}-0.060 \cdot C_{L i F}+C
$$

where $\Delta \eta_{i}$ is the current efficiency loss, $\Delta T$ is the superheat, $C_{A l F_{3}}-$ wt. $\%$ of $\mathrm{AlF}_{3}, C_{L i F}-$ wt. $\% \mathrm{LiF}, C-$ numerical constant related to the cell functioning

Korenko et al. [26] [27] investigated the impact of $\mathrm{SiO}_{2}$ content on the electrical conductivity and viscosity of the cryolite mixture $\left(\mathrm{NaF}-\mathrm{AlF}_{3}\right.$ of eutectic composition) in tube-cell (fabricated with pyrolytic boron nitride) with stationary electrodes. In range of 0 to 10 mole $\%$ of $\mathrm{SiO}_{2}$, the conductivity increased and in a range of 10 to 40 mole \% the drop in the electrical conductivity was observed. Equation (4) shows the relationship between the electrical conductivity and the $\mathrm{SiO}_{2}$ content.

$$
\kappa=1.127-0.01750 \cdot C_{\mathrm{SiO}_{2}}+0.001789 \cdot \mathrm{T}
$$

where $\kappa$ is the electrical conductivity in $\mathrm{S} / \mathrm{cm}, T$ is the temperature (950-1120) in ${ }^{\circ} \mathrm{C}$ and $\mathrm{C}_{\mathrm{SiO}_{2}}$ is the mole fraction of $\mathrm{SiO}_{2}$.

The viscosity of $\mathrm{NaF}_{-} \mathrm{AlF}_{3}-\mathrm{SiO}_{2}$ mixture decreases while the content of $\mathrm{SiO}_{2}$ is raised from 0 to 10 mole \% and starts to increase when the $\mathrm{SiO}_{2}$ proportion is from 10 to 40 mole \%. Equation (5) is formulated by using regression modelling to demonstrate the relation between viscosity, $\mathrm{SiO}_{2}$ content and temperature.

$$
\mu=19.85-0.01737 \cdot T+0.07618 \cdot C_{\mathrm{SiO}_{2}}
$$

where $\mu$ is the viscosity of the melt in mPas, $T$ is the temperature $(1010-1120)$ in ${ }^{\circ} \mathrm{C}$ and $C_{S_{i O}}$ is the mole fraction of $\mathrm{SiO}_{2}$.

The viscosity of the melt increases with high proportions of $\mathrm{SiO}_{2}$ because of the formation of complex ions like $\mathrm{SiO}_{4}^{4-}, \mathrm{Si}_{2} \mathrm{O}_{7}^{6-}$ and $\mathrm{Si}_{3} \mathrm{O}_{10}^{8-}$ as they lead to the growth of the bigger network structure [28]. The inclusion of basic oxides in the melts destroys the network structure of complex ions resulting the reduction of viscosity of the melts. The relation between the electrical conductivity and viscosity was discussed by Zhang et al. [29], where the electrical conductivity increases as the viscosity decreases.

Solubility of aluminum in sodium cryolite melt was determined by Vasyunina et al. [27]. The samples of the melt were frequently tested by rapid cooling the electrolyte samples and the content of metal present in the melt was determined by using the gas volumetric analysis. The influence of additives such as lithium fluoride, aluminum fluoride and potassium fluoride on the solubility of aluminum in the melt was also determined. Few conclusions were made:

1. Decrease in the $\mathrm{CR}\left(\mathrm{NaF} \mathrm{mol} \% / \mathrm{AlF}_{3} \mathrm{~mol} \%\right)$ from 2.5 to 2.2 at a constant overheating with the saturation of the electrolyte with alumina reduces the solubility of the metal from 0.042 to 0.023 wt.\%.

2. Further decrease of the CR, less than 2.1 does not show any influence on the solubility of the metal in the melt.

3. Addition of $5 \mathrm{wt} . \%$ of KF considerably reduces the solubility of the aluminum in the melt.

4. An introduction of $3 \mathrm{wt} . \%$ of $\mathrm{LiF}$ reduces the aluminum solubility.

5. The increase in $\mathrm{CaF}_{2}$ from 4 to $6 \mathrm{wt} . \%$ increases the solubility of the metal in the melt.

Dissolution rate of alumina in $\mathrm{NaF}-\mathrm{AlF}_{3}-\mathrm{Al}_{2} \mathrm{O}_{3}$ was studied by reducing the $\mathrm{CR}$ value less than 2.1 to make the melt acidic by increasing the $\mathrm{AlF}_{3}$ content in order to achieve high current efficiencies [31]. Reducing the CR value decreases the solubility of aluminum in the melt increasing the current efficiency and droping the liquidus temperature of the electrolyte giving the scope to use inert anodes. It was noted that by reducing CR below 2.1 up to 1.5 , there is a drastic drop in the solubility and dissolution rate of alumina in the melt. The authors also mentioned that a cell with $300 \mathrm{kA}$ load could only achieve proper electrolysis operation when the $\mathrm{CR}$ is greater than 1.8 , as low $\mathrm{CR}$ values minimize the dissolution rate of alumina.

The density of sodium cryolite when $\mathrm{AlPO}_{4}$ is added was investigated in [32]. Sodium cryolite melts with different $\mathrm{CR}$ (1.5-3.0) were tested to determine their density. It was determined that for the sodium cryolite with $\mathrm{AlPO}_{4}$ additive, the density of the system decreases with decrease in the CR of the 
melt. The density of the system linearly decreases as the $\mathrm{AlPO}_{4}$ content increases as shown in equation (6). The density of the melt almost remains the same at CR 3.0 irrespective of the increase in the $\mathrm{AlPO}_{4}$ content.

$$
\rho=1.7217-0.00142 \cdot \mathrm{C}_{\mathrm{AlPO}_{4}}+0.1490 \cdot \mathrm{CR}
$$

where $\rho$ is the density of the $\left(\mathrm{NaF}-\mathrm{AlF}_{3}\right)-\mathrm{AlPO}_{4}$ melt in $\mathrm{g} / \mathrm{cm}^{3}, C_{\mathrm{AlPO}_{4}}$ is the wt.\% $\mathrm{AlPO}_{4}$,

Kubinakova et al. [33] determined the effect of additives in composite form of $\mathrm{Al}_{2} \mathrm{O}_{3}-\mathrm{CaF}_{2}$, $\mathrm{Al}_{2} \mathrm{O}_{3}-\mathrm{MgF}_{2}$ and $\mathrm{Al}_{2} \mathrm{O}_{3}-\mathrm{CaF}_{2}-\mathrm{LiF}$ in low-temperature sodium cryolite. Studies found that an increase in the concentration of $\mathrm{AlF}_{3}$ up to $45 \mathrm{~mol} \%$ decreases the melting temperature of the electrolyte to $700{ }^{\circ} \mathrm{C}$ as well as decreases the electrical conductivity. Findings show that the $\mathrm{Al}_{2} \mathrm{O}_{3}, \mathrm{CaF}_{2}$ and $\mathrm{MgF}_{2}$ causes the decline in the electrical conductivity of the multi-structural electrolyte except LiF, which improves the electrical conductivity. The reason behind the decrease in the electrical conductivity with the addition of $\mathrm{CaF}_{2}$ and $\mathrm{MgF}_{2}$ is that the $\mathrm{Ca}^{2+}$ and $\mathrm{Mg}^{2+}$ cations have high charge densities forming anionic complexes obstructing the path of charge carriers [34],[35]. Kubinakova et al. [33] formulated an equation (7) to show the dependence of the compositions on the electrical conductivity of the system. The research conducted in the past by Hives et al. [36] and Fellner et al. [37] reflected the same results. Increase in the composition of $\mathrm{CaF}_{2}$ and $\mathrm{MgF}_{2}$ in the melt lowers the conductivity $(\kappa)$.

$$
\begin{aligned}
& \kappa=3.521-3.749 \cdot C_{\mathrm{AlF}_{3}}+C_{\mathrm{Al}_{2} \mathrm{O}_{3}} \cdot\left(18.959-75.984 \cdot C_{\mathrm{AlF}_{3}}\right)-0.828 \cdot C_{\mathrm{CaF}_{3}}+C_{\mathrm{MgF}_{2}} \cdot\left(4.00-13.585 C_{\mathrm{AlF}_{3}}\right)+ \\
& C_{L i F} \cdot\left(-4.773+10.806 \cdot C_{\mathrm{AlF}_{3}}\right)
\end{aligned}
$$

where $C_{\mathrm{AlF}_{3}}$ is the wt. $\%$ of $\mathrm{AlF}_{3}, C_{\mathrm{Al}_{2} \mathrm{O}_{3}}$ is the wt. $\%$ of $\mathrm{Al}_{2} \mathrm{O}_{3}, C_{\mathrm{CaF}_{3}}$ is the wt. $\%$ of $\mathrm{CaF}_{3}, C_{\mathrm{MgF}_{2}}$ is the wt. $\%$ of $\mathrm{MgF}_{2}$ and $C_{L i F}$ is the wt.\% of $\mathrm{LiF}$.

Bao et al. [38] investigated the influence of $\mathrm{ZrO}_{2}$ on the electrical conductivity when added to $\mathrm{NaF}-\mathrm{AlF}_{3}-\mathrm{CaF}_{2}-\mathrm{Al}_{2} \mathrm{O}_{3}-\mathrm{ZrO}_{2}$ melt. The tests were carried out in a tube type cell with a fixed cell constant. A study was carried out for five different CR's by varying the wt.\% of $\mathrm{ZrO}_{2}$ from 0 to 5. An increase in $1 \mathrm{wt} . \%$ of $\mathrm{ZrO}_{2}$ reduces the electrical conductivity of the melt by $0.02 \mathrm{~S} / \mathrm{cm}$ with a temperature range of $950-1010{ }^{\circ} \mathrm{C}$. Increase in the $\mathrm{CR}\left(\mathrm{NaF} \mathrm{mol} \% / \mathrm{AlF}_{3} \mathrm{~mol} \%\right)$ improves the electrical conductivity as the decrease in the concentration of $\mathrm{AlF}_{3}$ reduces the number of complex ions and enhancing the number of mobility ions. The regression equation (8) is formulated based on the data acquired by Bao et al. [38].

$$
\kappa=0.004933 \cdot T-0.03101 \cdot C_{\mathrm{ZrO}_{2}}+0.6616 \cdot \mathrm{CR}-4.112
$$

where $C_{\mathrm{ZrO}_{2}}$ is the wt. $\%$ of $\mathrm{ZrO}_{2}, \mathrm{CR}$ ranging from 2.2 to 2.5 , temperature ranging from 950 to $1010{ }^{\circ} \mathrm{C}$

Frazer et al. [39] determined the alumina solubility and the diffusion rate of dissolved alumina in $\mathrm{NaF}-\mathrm{AlF}_{3}$ eutectic melt. The solubility is said to be $3.2 \pm 0.3 \mathrm{wt} \%$ in $\mathrm{NaF}-\mathrm{AlF}_{3}$ eutectic at $750{ }^{\circ} \mathrm{C}$.

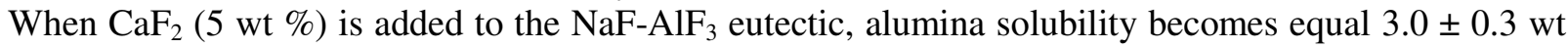
$\%$ at $750{ }^{\circ} \mathrm{C}$. It implies that the addition of $\mathrm{CaF}_{2}$ has the negative impact on the alumina solubility in the

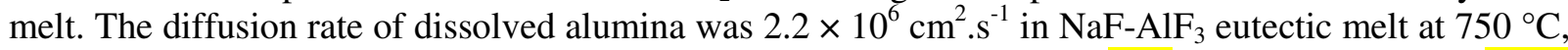
which is five times less than the value achieved through the traditional bath operated at $960^{\circ} \mathrm{C}$ (a low diffusion rate leads to a slow mass transfer).

The surface tension of the $\mathrm{NaF}_{-} \mathrm{AlF}_{3}$ system $\left(\mathrm{NaF} 55\right.$ mole $\%$ and $\mathrm{AlF}_{3} 45$ mole \%) with the temperature dependency was determined by Silny et al. [40]. The surface tension was obtained by knowing the maximum pressure exhibited by bubble formed on the tip of a capillary. The capillary is immersed in the molten cryolite to a known depth and at a given temperature. The maximum bubble pressure is reached when the bubble forms a hemisphere with a radius equalizing the radius of the capillary. The surface tension is calculated by using the following equation (9) from [41],

$$
\sigma=\frac{r}{2}\left(P_{\max }-g \rho h\right)
$$

where $r$ is the capillary radius, $P_{\max }$ is the maximum bubble pressure, $g$ is the gravitational constant, $\rho$ is the density of the melt and $h$ is the depth of immersion of the capillary.

The surface tension in the system decreases linearly with the temperature $\left(740\right.$ to $\left.815^{\circ} \mathrm{C}\right)$ as shown in equation (10): . 


$$
\sigma=2.6033-9.2738 \cdot 10^{-4} . T
$$

where $\sigma$ is the surface tension $\left({ }^{3} \mathrm{~N} / \mathrm{m}\right)$ and $T$ is the temperature in the range $(740-815){ }^{\circ} \mathrm{C}$

The influence of $\mathrm{Al}_{2} \mathrm{O}_{3}$ on the local-structure and transport properties of $\mathrm{NaF}^{\circ}-\mathrm{AlF}_{3}-\mathrm{Al}_{2} \mathrm{O}_{3}$ was investigated by $\mathrm{Lv}$ et al. [42]. The studies reveal that the $\mathrm{AlF}_{4}^{-}, \mathrm{AlF}_{5}^{2-}$ and $\mathrm{AlF}_{6}^{3-}$ complex ions exist simultaneously in $\mathrm{NaF}-\mathrm{AlF}_{3}-\mathrm{Al}_{2} \mathrm{O}_{3}$ molten system. At low $\mathrm{Al}_{2} \mathrm{O}_{3}$ concentrations (approximately 1-2 wt. $\%)$ in the melt, the most dominant complex ion is $\mathrm{AlF}_{6}^{3-}$. The $\mathrm{AlF}_{4}^{-}, \mathrm{AlF}_{5}^{2-}$ and $\mathrm{AlF}_{6}^{3-}$ complex ions have equal proportions in the molten salt when $\mathrm{Al}_{2} \mathrm{O}_{3}$ concentration is $3 \mathrm{wt} \%$ and the $\mathrm{AlF}_{4}^{-}$ion tends to be dominant among others when the $\mathrm{Al}_{2} \mathrm{O}_{3}$ concentration is $4 \mathrm{wt} \%$. Increase in the concentration of $\mathrm{Al}_{2} \mathrm{O}_{3}$ reduces the ionic conductivity of the molten salt and simultaneously raises the viscosity. It is due to the formation of complex structure in the molten salt as the $\mathrm{Al}_{2} \mathrm{O}_{3}$ acts as a bridge connecting the ionic structure networks, which increases the polymerization degree of local structure in the molten salt.

As earlier discussed, the formation of the fluoro-aluminates in the molten cryolite system depends on the CR as follows [6], [7], [8]:

1. The complex ions $\mathrm{AlF}_{4}^{-}, \mathrm{AlF}_{5}^{2-}, \mathrm{AlF}_{6}^{-3}, \mathrm{Al}_{2} \mathrm{O}_{2} \mathrm{~F}_{4}^{2-}$ and $\mathrm{Al}_{2} \mathrm{OF}_{6}^{2-}$ are formed at $1<\mathrm{CR}<3$

2. The $\mathrm{Al}_{3} \mathrm{O}_{4} \mathrm{~F}_{4}^{3-}$ complex ion is only formed at $3<\mathrm{CR}<4$ in alumina saturated melts.

\section{2 $\quad \mathrm{KF}-\mathrm{AlF}_{3}$ electrolyte and additives}

The low temperature melts were desirable for the electrolysis since long time as they reduce the corrosion rate of the cell parts and increase the cell lifetime. Pure potassium cryolite dissolves more alumina than sodium cryolite. But the electrical conductivity of the potassium cryolite is rather low and decreases with decrease of the temperature $\left(680-820^{\circ} \mathrm{C}\right.$ ) and increases with the increase in CR (mole fraction of KF divided by mole fraction of $\mathrm{AlF}_{3}$ ) between 2.2 and 3.0. The equation (11) was formulated by using the regression modeling from the data acquired by Kryukovsky et al. [43].

$$
\kappa=0.0026 \cdot T-0.8788
$$

$\mathrm{Xu}$ et al. [44] calculated the thermodynamic properties of $\mathrm{KF}^{-\mathrm{AlF}_{3}}$ and determined that the complex ions formed are $\mathrm{AlF}_{6}^{3-}, \mathrm{AlF}_{5}^{2-}$ and $\mathrm{AlF}_{4}^{-}$similar to that of the $\mathrm{NaF}-\mathrm{AlF}_{3}$ and $\mathrm{LiF}_{-} \mathrm{AlF}_{3}$ systems. The $\mathrm{AlF}_{6}^{3-}$ complex ion is tend to be more stable in the $\mathrm{KF}^{-\mathrm{AlF}_{3}}$ system than in the NaF- $\mathrm{AlF}_{3}$ or LiF$\mathrm{AlF}_{3}$ melts due to the weakest action of cation $\mathrm{K}^{+}$on the ligand $\mathrm{F}^{-}$. It makes the electrical conductivity of $\mathrm{KF}-\mathrm{AlF}_{3}$ lower than that of the $\mathrm{NaF}_{-} \mathrm{AlF}_{3}$ system where $\mathrm{AlF}_{6}^{3-}$ is dissociated into $\mathrm{AlF}_{5}^{2-}, \mathrm{AlF}_{4}^{-}$and $\mathrm{AlF}_{3}$ in steps resulting in the easy charge carriers transportation. The same was stated by Tsirlina et al. [45] and Nazmutdinov et al. [46].

The electrical conductivity of $\mathrm{KF}-\mathrm{NaF}-\mathrm{AlF}_{3}$ melts were investigated by Yang et al. [47]. The addition of KF in the sodium cryolite results in the decrease in the melting temperature. The continuously varying cell constant technique was used to measure the electrical conductivity of $\mathrm{KF}-\mathrm{NaF}-\mathrm{AlF}_{3}$ melt with varying parameters like $\mathrm{NaF}$ content, alumina content and $\mathrm{CR}$ at different temperatures. The effect of the $\mathrm{NaF}$ content on the conductivity of $\mathrm{KF}-\mathrm{NaF}-\mathrm{AlF}_{3}$ melt was examined. The cryolite ratio of this particular melt is the sum of mole fraction of $\mathrm{NaF}$ and $\mathrm{KF}$ divided by the mole fraction of $\mathrm{AlF}_{3}$. At $\mathrm{CR}=1.3$ the conductivity of the melt was measured with following contents:

1. KF $57.4 \mathrm{~mol} \%$;

2. NaF 15 mol\% KF 42.7 mol\%;

3. $\mathrm{NaF} 30 \mathrm{~mol} \%, \mathrm{KF} 27.4 \mathrm{~mol} \%$;

4. $\mathrm{NaF} 45 \mathrm{~mol} \%$, KF $12.4 \mathrm{~mol} \%$ and

5. $\mathrm{NaF} 57.4 \mathrm{~mol} \%$

The temperatures were in the range from $750-820^{\circ} \mathrm{C}$ with $10^{\circ} \mathrm{C}$ interval. The dependence can be expressed by the equation (12).

$$
\kappa=0.002776 \cdot T+0.001393 \cdot C_{N a F}-0.0192
$$

where $C_{N a F}$ is the mole $\%$ of $\mathrm{NaF}$ in the $\mathrm{NaF}-\mathrm{KF}-\mathrm{AlF}_{3}$ system.

This is due to the fact that the radius of $\mathrm{Na}^{+}\left(1.02 \times 10^{-10} \mathrm{~m}\right)$ is smaller than $\mathrm{K}^{+}\left(1.38 \times 10^{-10} \mathrm{~m}\right)$ and hence, the $\mathrm{Na}^{+}$ion migration speed is tend to be higher than that of $\mathrm{K}^{+}$, which 
is the reason why the electrical conductivity of the melts increases with the increase of $\mathrm{NaF}$ content. Similarly, the electrical conductivity was calculated by varying the alumina content and changing CR for different temperatures between $750-820^{\circ} \mathrm{C}$ with $10^{\circ} \mathrm{C}$ interval and the findings show that with an increase in the alumina content, the electrical conductivity decreases and with an increase in $\mathrm{CR}$, the conductivity increases.

Apisarov et al. [48] measured the electrical conductivity of the $\mathrm{KF}-\mathrm{AlF}_{3}$ system containing $\mathrm{LiF}$ and alumina. It was determined that by increasing $\mathrm{LiF}$ content, the electrical conductivity of the molten electrolyte increases and by increasing alumina content, the electrical conductivity slightly drops. Equation (13) shows the relation between the conductivity, the temperature and the content of alumina in the electrolyte composition at $\mathrm{CR}=1.3\left(\mathrm{KF} \mathrm{mol} \% / \mathrm{AlF}_{3} \mathrm{~mol} \%\right)$

$$
\kappa=0.1336+0.001547 \cdot T-2.25 \cdot C_{\mathrm{Al}_{2} \mathrm{O}_{3}}
$$

where, $C_{\mathrm{Al}_{2} \mathrm{O}_{3}}$ is the wt. $\% \mathrm{Al}_{2} \mathrm{O}_{3}$ in $\mathrm{KF}-\mathrm{AlF}_{3}-\mathrm{Al}_{2} \mathrm{O}_{3}(\mathrm{CR}=1.3)$ electrolyte. $T=680-800^{\circ} \mathrm{C}$.

For all compositions (w.t.r. to LiF content) the electrical conductivity of the melt increases with a temperature raise. The equation (14) was derived as below:

$$
\kappa=0.0351+0.001692 \cdot T+1.375 \cdot C_{L i F}
$$

where, $C_{L i F}$ is the wt. $\% \mathrm{LiF}$ in $\mathrm{KF}-\mathrm{AlF}_{3}-\mathrm{LiF}(\mathrm{CR}=1.3)$ melt. $T=680-800^{\circ} \mathrm{C}$

The liquidus temperature and the density of the $\mathrm{KF}-\mathrm{AlF}_{3}$ system with the addition of $\mathrm{AlPO}_{4}$ to the melt was determined by Vaskova et al. [49]. The liquidus temperature and the density of the system was determined for $1.5 \leq \mathrm{CR} \leq 3$ and at different $\mathrm{AlPO}_{4}$ contents. The liquidus temperature of the system tends to decrease with the increase in the $\mathrm{AlPO}_{4}$ content and as the $\mathrm{CR}$ is reduced, the liquidus temperature of $\left(\mathrm{KF}-\mathrm{AlF}_{3}\right)-\mathrm{AlPO}_{4}$ system falls (figure 3$)$.

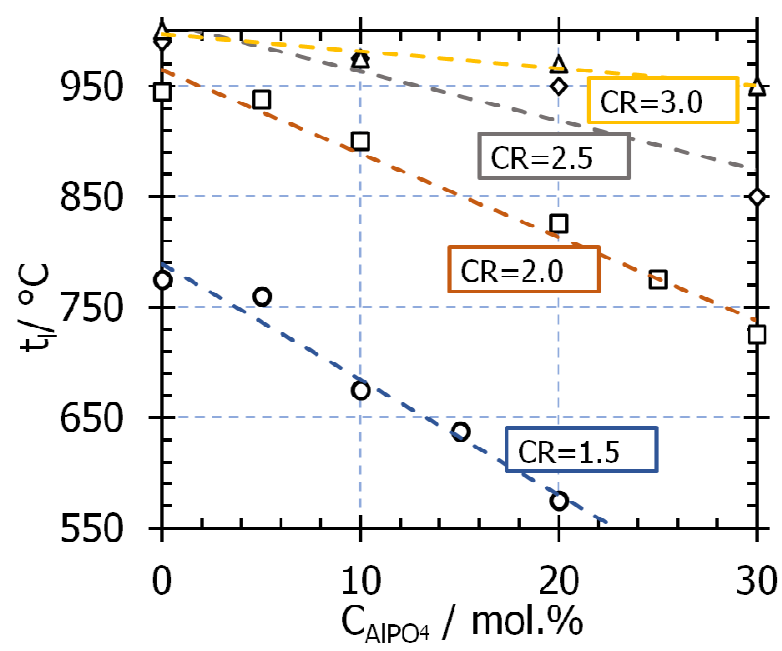

Figure 3 - Liquidus temperatures of $\left(\mathrm{KF}-\mathrm{AlF}_{3}\right)-\mathrm{AlPO}_{4}$ system at different cryolite ratios with increasing $\mathrm{AlPO}_{4}$ content [49]

The density of the system also decreased with an increase in the $\mathrm{AlPO}_{4}$ content and increases with an increase in CR. The density of the system almost remains the same at $\mathrm{CR} \geq 3.0$ irrespective of the increase in the $\mathrm{AlPO}_{4}$ content similar to the $\mathrm{NaF}-\mathrm{AlF}_{3}-\mathrm{AlPO}_{4}$ system that can be seen in figure 4. 


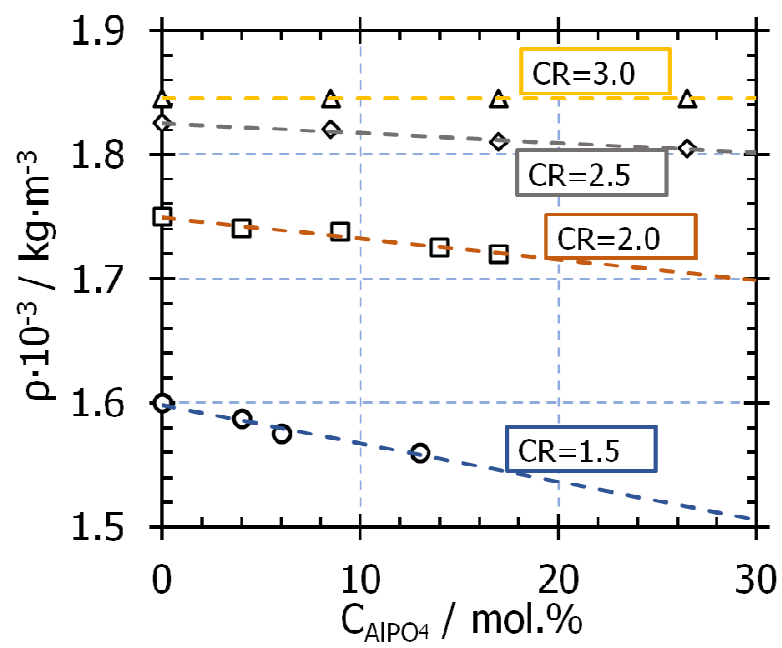

Figure 4 - Density of $\left(\mathrm{NaF}-\mathrm{AlF}_{3}\right)-\mathrm{AlPO}_{4}$ system, at $1050{ }^{\circ} \mathrm{C}$, at various $\mathrm{CR}$ [49]

\subsection{Chloride melts}

Even though fluoride melts are used for aluminum electrolysis, the desire to use low temperature electrolytes have made researchers to do extensive research towards chloride melts. Mostly, the Chloride melt would be the combination of $\mathrm{AlCl}_{3}$ and alkali metal halides like $\mathrm{NaCl}, \mathrm{LiCl}$, $\mathrm{KCl}, \mathrm{BeCl}_{2}, \mathrm{CaCl}_{2}, \mathrm{MgCl}_{2}, \mathrm{BaCl}_{2}$. Usually $\mathrm{NaCl}$ is highly preferred, as $\mathrm{AlCl}_{3}-\mathrm{NaCl}$ combination has low melting temperature. $\mathrm{AlCl}_{3}, \mathrm{Al}_{2} \mathrm{~S}_{3}$ and other materials [50] have considerably high solubility in chlorides. The electrical conductivity of various chloride melts at different operating conditions and molar fractions were discussed by Redkin et al. [50]

Minh et al. [51] investigated the electrolysis of $\mathrm{Al}_{2} \mathrm{~S}_{3}$ at $750^{\circ} \mathrm{C}$ by using $\mathrm{AlCl}_{3}-\mathrm{MgCl}_{2}-$ $\mathrm{NaCl}-\mathrm{KCl}$ electrolyte, as $\mathrm{Al}_{2} \mathrm{~S}_{3}$ dissolve in the electrolyte and electrolysis produces aluminium and sulphur. The anodic current density plays a crucial role in this process and it varies in the range $0.2-$ $1.2 \mathrm{~A} / \mathrm{cm}^{2}$ with current efficiencies of $75-85 \%$ (the efficiency increases with the increase of the current density). Dependence between solubility of $\mathrm{Al}_{2} \mathrm{~S}_{3}\left(\mathrm{C}_{\mathrm{Al2S} 3}^{\mathrm{s}}\right)$ and the composition of electrolyte is shown in figure 5.

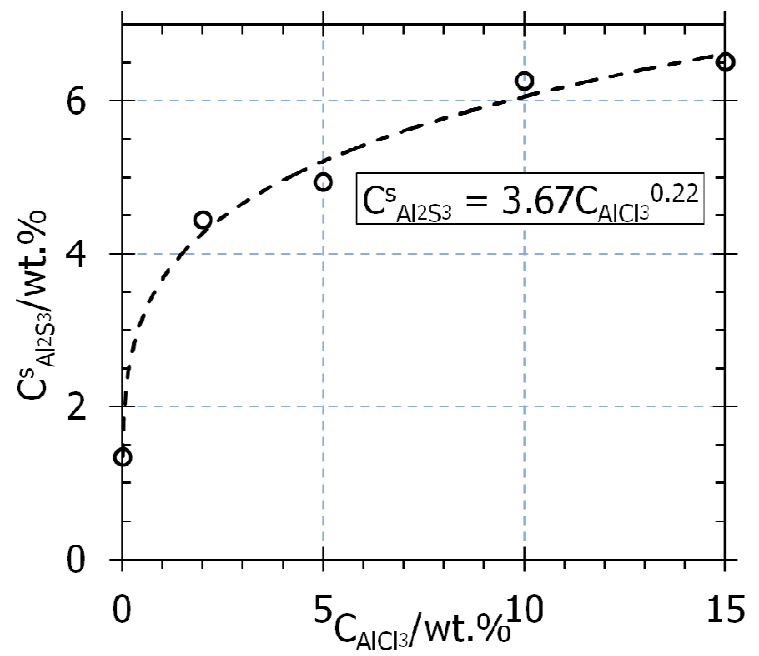

Figure 5 - Solubility of $\mathrm{Al}_{2} \mathrm{~S}_{3}$ vs. $\mathrm{AlCl}_{3}$ content $\left(\mathrm{C}_{\mathrm{AlCl} 13}\right)$ in the melt [50]

The cathode has a limiting current density of $0.3 \mathrm{~A} / \mathrm{cm}^{2}$ resulting in the low productivity. It was observed that the solubility of $\mathrm{Al}_{2} \mathrm{~S}_{3}$ strictly depends on the amount of $\mathrm{AlCl}_{3}$ added in the electrolyte where the solubility of aluminum sulphur increases with the increase in the content of $\mathrm{AlCl}_{3}$ in the melt and can be seen in Figure 5. 
The reduction of aluminum was performed in theCaCl $2-\mathrm{NaCl}-\mathrm{Al}_{2} \mathrm{O}_{3}$ molten electrolyte with $71 \sim 87 \mathrm{wt} . \%$ of $\mathrm{CaCl}_{2}$ (the rest being $\mathrm{NaCl}$ ) by Xie et al. [52]. The temperature was varied between 550 $800^{\circ} \mathrm{C}$. Electrical conductivity was measured. From acquired results an equation (15) was formulated.

$$
\kappa=-1.300+0.0044 \cdot \mathrm{T}-0.04 \cdot \mathrm{C}_{\mathrm{Al}_{2} \mathrm{O}_{3}}
$$

where $\mathrm{C}_{\mathrm{Al}_{2} \mathrm{O}_{3}}$ is the wt. $\% \mathrm{Al}_{2} \mathrm{O}_{3}$ in the $\mathrm{CaCl}_{2}-\mathrm{NaCl}-\mathrm{Al}_{2} \mathrm{O}_{3}$ system, $T=550-750^{\circ} \mathrm{C}$

With an increase in the $\mathrm{CaCl}_{2}$ content, the electrical conductivity and the density of the electrolyte decreases . Equation (16) illustrates the effect of the increased $\mathrm{CaCl}_{2}$ content on the electrical conductivity of the electrolyte. Conclusion is made by saying that the $\mathrm{CaCl}_{2}$-based electrolyte can actually be used and its lower melting temperature seems to be an attractive property.

$$
\kappa=0.221+0.003664 \cdot T-1.584 \cdot C_{\mathrm{CaCl}_{2}}
$$

where $C_{\mathrm{CaCl}_{2}}$ is the wt. $\% \mathrm{CaCl}_{2}$ in $\mathrm{CaCl}_{2}-\mathrm{NaCl}-\mathrm{Al}_{2} \mathrm{O}_{3}$ melt, $T=600-800^{\circ} \mathrm{C}$

Balaraju et al. [53] investigated the solubility of alumina in the $\mathrm{NaF}-\mathrm{KCl}-\mathrm{Al}_{2} \mathrm{O}_{3}$ mixture. The studies showed that with increase in the $\mathrm{NaF}$ content in the mixture, the alumina solubility tends to increase. That can be clearly seen in Table 1 .

Table 1. Solubility of Alumina (Mass Percent, $100 \mathrm{w}$ ) in Molten NaF-KCl Mixtures

\begin{tabular}{|c|c|}
\hline Composition of KCl-NaF (mole \%) & Alumina solubility (100 w) \\
\hline $80-20$ & $0.5\left(740{ }^{\circ} \mathrm{C}\right)$ \\
\hline $70-30$ & $0.9\left(760^{\circ} \mathrm{C}\right)$ \\
\hline $50-50$ & $1.1\left(740^{\circ} \mathrm{C}\right)$ \\
\hline $30-70$ & $1.2\left(650^{\circ} \mathrm{C}\right)$ \\
\hline $20-80$ & $1.2\left(670^{\circ} \mathrm{C}\right)$ \\
\hline
\end{tabular}

\subsection{Suspension electrolyte}

The concept of suspension electrolyte was developed by T.R. Beck. The main idea of using suspension electrolyte is to maintain it saturated with alumina, to reduce the solubility of oxides, to minimize the corrosion rate of non-carbon anodes and to increase the cell lifetime. In [54] a eutectic $\mathrm{NaF}-\mathrm{AlF}_{3}$ melt with and without addition of $\mathrm{KF}-\mathrm{AlF}_{3}$ and $\mathrm{LiF}-\mathrm{AlF}_{3}$ was examined in 1-40 A laboratory cell at around $750^{\circ} \mathrm{C}$. Copper anode and $\mathrm{TiB}_{2}$ cathode were used and the alumina particles were fed in suspension at anode-electrolyte interface to avoid anode effect. The oxygen evolved at the anode keeps the alumina particles suspended, so it is important to have a continuous removal of the aluminum from the cell having an auxiliary anode to avoid the stoppage of oxygen evolution from the anode .

The cell would have a thermodynamic potential of $2.35 \mathrm{~V}$. The anodic overvoltage of $0.3 \mathrm{~V}$ was measured at $0.5 \mathrm{~A} / \mathrm{cm}^{2}$ current density and the cathodic overvoltage was negligible. The bath's ohmic drop for anode cathode distance of $1.3 \mathrm{~cm}$ was said to be $0.65 \mathrm{~V}$. The effective bath conductivity was said to be $1.0 \mathrm{~S} / \mathrm{cm}$. The current efficiency of the cell was reported to be $50 \%$ and it depends on the surface area of the aluminum $(A)$ near the anode to current supplied $(I)$. The current efficiency increases with the decrease in $(A / I)$ ratio and this can be achieved by consistent removal of aluminum near the anode and if this is implemented accurately, nearly $100 \%$ current efficiency can be achieved.

Theodore R. Beck proposed commercial cell design, which uses alumina slurry in the electrolyte, with the conditions mentioned in his patents [55]-[57]:

- A eutectic $\mathrm{NaF}-\mathrm{AlF}_{3}$ electrolyte with freezing point of $695{ }^{\circ} \mathrm{C}$ with the combination of $\mathrm{KF}-\mathrm{AlF}_{3}$ and $\mathrm{LiF}-\mathrm{AlF}_{3}$ eutectics having melting temperature of $750^{\circ} \mathrm{C}$. electrolyte.

- Alumina slurry content of $5-10 \mathrm{wt} . \%$ with particle size of less than $10 \mu \mathrm{m}$ is added to the

- Vertical copper mono-polar anode and Titanium boride cathode with the minimum anode cathode distance at around $1.3 \mathrm{~cm}$.

- Continuous removal of aluminum to maintain better current efficiency.

- The horizontal auxiliary oxygen evolving anode which avoids settling down of alumina particles at the bottom. 
Yasinskiy et al. [58], [59] investigated the sedimentation behavior of alumina suspension based on low-temperature electrolyte system $\mathrm{KF}-\mathrm{AlF}_{3}-\mathrm{Al}_{2} \mathrm{O}_{3}$. The value of maximum packing fraction for smelter grade alumina was estimated to be approximately as high as 0.32 at which the particles have extremely low or zero sedimentation velocity. The main factors determining this value were named to be poly-dispersity (which was calculated to be 0.42 ), the high porosity and the structural barrier which eliminates sedimentation of the particles.

\section{Relative electrical conductivity of suspension electrolyte}

The relative conductivity $\kappa / \kappa_{L}$ (where $\kappa$ - is the effective electrical conductivity of suspension, $\kappa_{L}$ - is the electrical conductivity of pure liquid phase) plays an important role when suspended electrolyte is used as it determines the voltage drop and the specific energy consumption of the cell. Maxwell's model [62] for the prediction of $\kappa / \kappa_{L}$ with the presence of suspension particles volume fraction $\varphi$ when they act as insulators is given by:

$$
\frac{\kappa}{\kappa_{L}}=1-\frac{3}{2} \phi
$$

It is shown in [63], [64] that Bruggeman's model predicts the $\kappa / \kappa_{L}$ better, when particles are multi-sized and randomly distributed:

$$
\frac{\kappa}{\kappa_{L}}=(1-\phi)^{3 / 2}
$$

The ratio $\kappa / \kappa_{L}$ of a two-phase system (suspension or foam) is considered to not depend on the nature of phases, but only on the volume fraction, shape and size of dispersed non-conductive phase $\varphi$.

\subsection{Experiment}

The experiment was carried out to find $\kappa / \kappa_{L}$ of the suspension electrolyte as a function of the alumina volume fraction $(\phi)$. Similarity criteria [60], [61] is used to design the water model cell and electrolyte composition ( $20 \%$ water solution of $\mathrm{H}_{2} \mathrm{SO}_{4}+0.28 \mathrm{M} \mathrm{CuSO}_{4}$ ) with a base being distilled water. Smelter grade alumina was provided by RUSAL (Krasnoyarsk, Russia) with $98.7 \%$ purity and $100 \mathrm{~m}^{2} / \mathrm{g}$ specific surface area.

The ratio $\kappa / \kappa_{\mathrm{L}}$ was determined from the equation

$$
\kappa=\frac{l \cdot I}{\Delta U_{O h m} \cdot S}
$$

where $l / S=K$ - is the vessels constant, $I$ - current, $\Delta U_{O h m}$ - Ohmic voltage drop, determined by $i$ interrupt technique with potentiostat Autolab PGSTAT302n.

As $K$ and $I$ were constant in parallel experiments, $\kappa / \kappa_{L}$ is proportional to $\Delta \mathrm{U}_{O h m}^{L} / \Delta \mathrm{U}_{\mathrm{Ohm}}$, where $\Delta U_{O h m}^{L}-$ is the Ohmic voltage drop of pure liquid electrolyte.

To evaluate the additional effect of bubbles generated at the anode and copper deposited at the cathode due the electrolysis, the experiments were conducted at five different current densities $i_{a}: 0.14$, $0.18,0.22,0.25 \mathrm{~A} / \mathrm{cm}^{2}$ at $50^{\circ} \mathrm{C}$. Nova 2.1.2 software was used to set $I$.

\subsection{Results and discussion}

The $\kappa / \kappa_{\mathrm{L}}$ ratios were determined, compared with Maxwell's and Bruggeman's models and presented in figure 6 . 


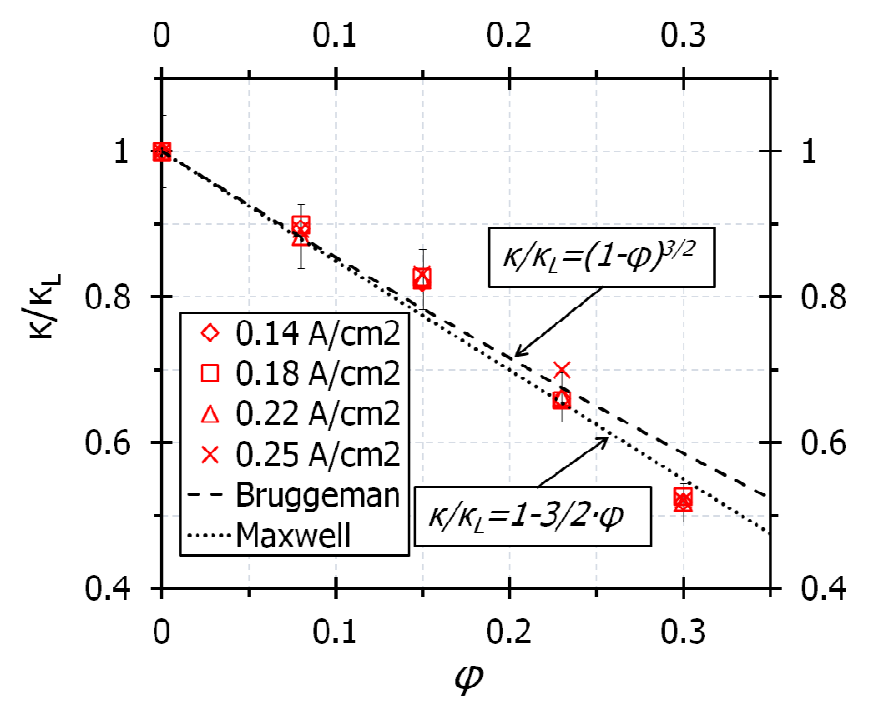

Figure 6 - Relative electrical conductivity $\left(\kappa / \kappa_{L}\right)$ at different current densities $i_{a}$ vs. alumina volume fraction $(\phi)$

An increase in $\phi$ tends to decrease $\kappa$ and $\kappa / \kappa_{L}$, which is in a good agreement with Cruz et al. [65] for high ionic strength liquids. The $\kappa / \kappa_{L}$ ratio determined experimentally at high $\varphi$ is lower than predicted values from the Bruggeman's model. The reason might be the influence of bubbles trapped in the suspension on the true volume fraction of non-conductive phase. The values at $\varphi=0.15$ are higher than predicted ones, which is probably due to experimental error. The deviation from the models increases with $\varphi$, which can be explained by the fact that the effective viscosity increases, and $\varphi$ is getting closer to maximum packing fracture estimated in [58] to be $\sim 0.32$. It leads to the increase of the bubble volume fraction. The accuracy of experimental data has been estimated and mentioned in the graph in the form of error bars showing the standard deviation.

In the studied range of $i_{a}$ gas generation rate (which is controlled by $i_{a}$ ) does not affect relative conductivity which is evidence for low experimental error introduced by the presence of gas and copper flow. Nevertheless the presented results do not have high accuracy ( minor experimental error), it can be stated that the described models still can be used to characterize suspension systems in industrial processes when the precious measurements cannot be achieved.

\section{Conclusion}

In the article, properties of sodium cryolite, potassium cryolite, chloride based melt and suspension electrolyte are discussed. Sodium cryolite basically has high melting temperature. The melting temperature can be reduced by adding additives like calcium fluoride but it has negative effect on the electrical conductivity of the electrolyte. Potassium cryolite is a good option as it can be operated at low-temperatures. It has a poor electrical conductivity and good solubility of alumina, the vapor pressure of the system is lower than that of $\mathrm{NaF}-\mathrm{AlF}_{3}$ system because of the strong complex ions formed as latter tends to have highly diffusive ions. An addition of lithium fluoride to potassium cryolite can improve the electrical conductivity. Chloride melts can be operated at low-temperatures and aluminum chloride electrolysis can be performed by using chloride melts but high purity of $\mathrm{AlCl}_{3}$ feed is required. Suspension electrolyte and cell design proposed by Beck seems promising. By adopting Beck's cell design, the cell geometry can be reduced, inert anode can be used. Inert anodes are desired to be used for its longer lifetime; electrolytes with low melting temperature are needed to avoid the anode corrosion of the anode. Table 2 gives the overview of the entire paper. An increase in the alumina volume fraction in the suspension electrolytic system tends to decrease the relative electrical conductivity. The electrolyte should maintain an acceptable current density and moderate alumina solubility at the low working temperature. Further research still has to be done in all the cases to obtain suitable conditions both to find a suitable electrolyte for electrolysis and novel processes [2]. 
Table 2. Effect of additives on the properties of the electrolyte

\begin{tabular}{|c|c|c|}
\hline Electrolyte & Additives & Effects of the additives \\
\hline $\mathrm{NaF}-\mathrm{AlF}_{3}$ & $\mathrm{CaF}_{2}$ & $\begin{array}{l}\text { Decreases electrical conductivity, decreases melting temperature [24], } \\
\text { increases viscosity [66] }\end{array}$ \\
\hline $\mathrm{NaF}-\mathrm{AlF}_{3}$ & $\mathrm{LiF}$ & Increases current efficiency, increases electrical conductivity [25] \\
\hline $\mathrm{NaF}-\mathrm{AlF}_{3}$ & $\mathrm{AlPO}_{4}$ & Decreases density [32] \\
\hline $\mathrm{NaF}-\mathrm{AlF}_{3}$ & $\mathrm{NaVO}_{3}$ & Increases density [32] \\
\hline $\mathrm{NaF}-\mathrm{AlF}_{3}$ & $\begin{array}{l}\mathrm{Al}_{2} \mathrm{O}_{3^{-}} \\
\mathrm{MgF}_{2}\end{array}$ & Decreases electrical conductivity [33] \\
\hline $\mathrm{NaF}-\mathrm{AlF}_{3}$ & $\mathrm{SiO}_{2}$ & $\begin{array}{l}\text { Increases electrical conductivity, decreases viscosity (when } \mathrm{C}_{\mathrm{SiO}_{2}}=0-10 \\
\text { mol.\%), decreases electrical conductivity, increases viscosity (when } \mathrm{C}_{\mathrm{SiO}_{2}}= \\
11-40 \text { mol.\%) [26], [27] }\end{array}$ \\
\hline $\mathrm{NaF}-\mathrm{AlF}_{3}$ & $\mathrm{ZrO}_{2}$ & Decreases electrical conductivity [38] \\
\hline $\begin{array}{l}\text { KF-NaF- } \\
\mathrm{AlF}_{3}\end{array}$ & KF & Decreases melting point, decreases electrical conductivity [47] \\
\hline $\begin{array}{l}\text { KF-NaF- } \\
\mathrm{AlF}_{3}\end{array}$ & $\mathrm{~B}_{2} \mathrm{O}_{3}$ & Increases liquidus temperature [67] \\
\hline $\mathrm{KF}-\mathrm{AlF}_{3}$ & $\mathrm{LiF}$ & Increases current efficiency and electrical conductivity [48] \\
\hline $\mathrm{KF}-\mathrm{AlF}_{3}$ & $\mathrm{Al}_{2} \mathrm{O}_{3}$ & Decreases electrical conductivity [49] \\
\hline $\mathrm{KF}-\mathrm{AlF}_{3}$ & $\mathrm{AlPO}_{4}$ & Decreases density and liquidus temperature [50] \\
\hline $\begin{array}{c}\mathrm{AlCl}_{3^{-}} \\
\mathrm{MgCl}_{2^{-}} \\
\mathrm{NaCl}-\mathrm{KCl}\end{array}$ & $\mathrm{AlCl}_{3}$ & Increases solubility of $\mathrm{Al}_{2} \mathrm{~S}_{3}[51]$ \\
\hline $\begin{array}{l}\mathrm{CaCl}_{2^{-}} \\
\mathrm{NaCl}- \\
\mathrm{Al}_{2} \mathrm{O}_{3} \\
\end{array}$ & $\mathrm{CaCl}_{2}$ & Decreases electrical conductivity and increases the density [52] \\
\hline $\begin{array}{l}\mathrm{CaCl}_{2^{-}} \\
\mathrm{NaCl}- \\
\mathrm{Al}_{2} \mathrm{O}_{3}\end{array}$ & $\mathrm{NaCl}$ & Increases electrical conductivity [52] \\
\hline
\end{tabular}

\section{Acknowledgments}

The reported study was funded by Russian Foundation for Basic Research, Government of Krasnoyarsk Territory, Krasnoyarsk Region Science and Technology Support Fund to the research project № 18-48-243014.

\section{References}

[1]. Dietrich G. Altenpohl, "Aluminum: Technology, Applications and Environment: A Profile of a Modern Metal Aluminum from Within", 6th Edition, 1998, 488 p.

[2]. P.V. Polyakov, A.B. Klyuchantsev, A.S. Yasinskiy, Y.N. Popov, "Conception of "Dream Cell” In Aluminium Electrolysis", Light Metals, (2016) 283-288.

[3]. Warren Haupin, "The Influence of Additives on Hall-Heroult Bath Properties", JOM, November (1991) 28-32.

[4]. S.K. Ratkje. "Oxy-fluoro aluminate complexes in molten cryolite melts", Electrochimica acta, 21, (1976) 515 - 517.

[5]. Gerard S. Picard, Frederic C. Bouyer, Michel Leroy, Yves Bertaud, S. Bouvet, "Structures of oxyfluoroaluminates in molten cryolite-alumina mixtures investigated by DFT-based calculations", Journal of Molecular Structure (Theochem) , 368, (1996) 67-80. 
[6]. A. P. Khramov and N. I. Shurov, "Modern Views on the Composition of Anionic Oxy_Fluoride Complexes of Aluminium and Their Rearrangement during the Electrolysis of Cryolite_Alumina Melts", Russian Metallurgy (Metally), 2014 (8), (2014) 581-592.

[7]. E. Robert, J. E. Olsen, V. Danek, E. Tixhon, T. Ostvold, and B. Gilbert, "Structure and thermodynamics of alkali fluoride-aluminium fluoride-alumina melts. Vapor pressure, solubility and Raman spectroscopic studies," J. Phys. Chem. B, 101, (1997) 9447-9457.

[8]. $\quad$ F. Auguste, O. Tkatcheva, H. Mediaas, T. Östvold, and B. Gilbert, "The dissociation of fluoroaluminates in FLiNaK and CsF-KF Molten mixtures: a Raman spectroscopic and solubility study," Inorganic Chemistry, 42(20), (2003) 6338-6344.

[9]. Sergei D. Kirik, Yulia N. Zaitseva, Darya Yu. Leshok, Alexandr S. Samoilo, Petr S. Dubinin, Igor S. Yakimov, Dmitry A. Simakov and Alexandr O. Gusev, "NaF-KF-AlF 3 System: Phase Transition in $\mathrm{K}_{2} \mathrm{NaAl}_{3} \mathrm{~F}_{12}$ Ternary Fluoride", Inorganic Chemistry, 54(12), (2015) 5960-5969.

[10]. Alexander S. Samoilo, Yulia N. Zaitseva, Peter S. Dubinin, Oksana E. Piksina, Sergei G. Ruzhnikov, Igor S. Yakimov, Sergei D. Kirik, "Structural aspects of the formation of solid solutions in the NaF-KF-AlF 3 system", Journal of Solid State Chemistry, 252, (2017) 1-7.

[11]. $\quad$ R.P. Pawlek, "Inert Anodes: An Update", Light Metals, (2002) 1126-1133.

[12]. Padamata S.K., Yasinskiy A.S., Polyakov P.V. "Progress of inert anodes in aluminium industry: review", J. Sib. Fed. Univ. Chem., 11(1), (2018) 18-30.

[13]. Ioan Galasiu, Rodica Galasiu, Jomar Thonstad, "Inert anodes for Aluminium electrolysis", $1^{\text {st }}$ edition, Aluminium-Verlag, Düsseldorf, 2007, 207 p.

[14]. K. Grjotheim, C. Krohn, M. Malinovsky, K. Matiasovsky, J. Thonstad, "Aluminium Electrolysis- Fundamentals of Hall-Heroult Process", $2^{\text {nd }}$ edition, Aluminium-Verlag, Düsseldorf, 1982, $443 \mathrm{p}$.

[15]. Jomar Thonstad, Pavel Fellner, Geir Martin Haarberg, Jan Hives, Halvor Kvande, Asmund Sterten, "Aluminium Electrolysis- Fundamentals of Hall-Heroult Process", $3^{\text {rd }}$ edition, Aluminium-Verlag, Düsseldorf, 2001, 372 p.

[16]. U.S. Patent No. 4,214,956. Kenneth A. Bowman, "Electrolytic Purification of Metal", 1980.

[17]. U.S. Patent No. 5,015,342. Marco V. Ginatta, Gianmichele Orsello, Riccardo Berruti, "Method and Cell for the Electrolytic Production of a Polyvalent Metal", 1991.

[18]. U.S. Patent No. 5,279,715. Leroy E. Dastolfo, Jr., Lower Burrell, ALfred F. LaCamera, "Process for Low Temperature Electrolysis of Metals in a Chloride Salt Bath", 1995.

[19]. U.S. Patent No. 6,428,675. Kathleen M. Tomaswick, "Low Temperature Aluminum Production", 2002.

[20]. Nguyen Quang Minh, "Extraction of Metals by Molten Salt Electrolysis: Chemical Fundamentals and Design Factors", JOM, January, (1985) 28-33.

[21]. K. Grjotheim, M. Malinovsky, and K. Matiasovsky, "The Effect of Different Additives on the Conductivity of Cryolite-Alumina Melts", JOM, January, (1969) 29-33.

[22]. A. Solheim, S. Rolseth, E. Skybakmoen, L. Stoen, "Liquidus Temperature and Alumina Solubility in the System $\mathrm{Na}_{3} \mathrm{AlF}_{6}-\mathrm{AIF}_{3}-\mathrm{LiF}-\mathrm{CaF}_{2}-\mathrm{MgF}_{2}$ ", Light Metals, (1995) 73-82.

[23]. Jun-qing Wang, Chang-lin Li, Deng-peng Chai, Yun-feng Zhou, Bin Fang, and Qiang $\mathrm{Li}$, "Relationship between Aluminium Electrolysis Current Efficiency and Operating Condition in Electrolyte Containing High Concentration of Li and K", Light metals, (2018) 621-626.

[24]. A. Dedyukhin, A. Apisarov, P. Tin'ghaev, A. Redkin, Yu, Zaikov, "Electrical conductivity of the $\mathrm{KF}-\mathrm{NaF}-\mathrm{AlF}_{3}$ molten system at low cryolite ratio with $\mathrm{CaF}_{2}$ addition", Light metals, (2011) 563-565.

[25]. Ernest W. Dewing, "Loss of Current Efficiency in Aluminium Electrolysis Cell", Metallurgical Transaction B, 22B, (1991) 177-182.

[26]. Michal Korenko, Jozef Priscak, Frantisek Simko, "Electrical conductivity of system based on $\mathrm{Na}_{3} \mathrm{AlF}_{6}-\mathrm{SiO}_{2}$ melt", Chemical papers, 67 (10), (2013) 1350-1354.

[27]. Michal Korenko, Zuzana Vaskova, Frantisek Simko, Michal Simurda, Marta Ambrova, Zhong-ning Shi, "Electrical conductivity and viscosity of cryolite electrolytes for solar grade silicon (Si-SoG) electrowinning", Trans. Nonferrous Met. Soc. China, 24, (2014) 3944-3948. 
[28]. Guo-Hua Zhang, Bai-Jun Yan, Kuo-Chih Chou, Fu-Shen Li, "Relation between Viscosity and Electrical Conductivity of Silicate Melts", Metallurgical and Materials Transactions B, 42B, (2011) 261-264.

[29]. Guo-Hua Zhang and Kuo-Chih Chou, "Correlation between Viscosity and Electrical Conductivity of Aluminosilicate Melts", Metallurgical and Materials Transactions B, 43B, (2012) 849855 .

[30]. N. V. Vasyunina, I. P. Vasyunina, Yu. G. Mikhalev, and P. V. Polyakov, "Solubility of Aluminum in Cryolite-Alumina Electrolytes", Russian Journal of Non-Ferrous Metals, 2011, Vol. 52, No. 4, pp. 360-363, August 2012.

[31]. N. V. Vasyunina, I. P. Vasyunina, Yu. G. Mikhalev, and A. M. Vinogradov, "The Solubility and Dissolution Rate of Alumina in Acidic Cryolite Aluminous Melts", Russian Journal of Non-Ferrous Metals, Vol. 50, No. 4, pp. 338-342, 2009.

[32]. František Šimko, Iveta Macková, Zuzana Netriová, "Density of the systems $\left(\mathrm{NaF} / \mathrm{AlF}_{3}\right)-\mathrm{AlPO}_{4}$ and $\left(\mathrm{NaF} / \mathrm{AlF}_{3}\right)-\mathrm{NaVO}_{3}$ ", Chemical Papers, vol. 65, no. 1, pp. 85-89, 2011.

[33]. Emilia Kubinakova, Vladimir Danielik, Jan Hives, "Electrochemical characterization of multicomponent sodium cryolite electrolytes with high content of aluminium fluoride", Electrochimica Acta, 265, (2018) $474-479$.

[34]. E. W. Dewing, "Effect of additives on activities in cryolite melts", TMS-AIME, Light Metals, (1989) 303-307.

[35]. H. Zhou, O. Herstad and T. Ostvold, "Vapour pressure studies of and complex formation in $\mathrm{NaF}_{-} \mathrm{AlF}_{3}$ and $\mathrm{Na}_{3} \mathrm{AlF}_{6}-\mathrm{MgF}_{2}$ melts", TMS-AIME, Light Metals, (1992) 511-520.

[36]. J. Hives, J. Thonstad, A. Sterten and P. Fellner, "Electrical Conductivity of the Molten Cryolite-Based Ternary Mixtures $\mathrm{Na}_{3} \mathrm{AlF}_{6}-\mathrm{Al}_{2} \mathrm{O}_{3}-\mathrm{CaF}_{2}, \mathrm{Na}_{3} \mathrm{AlF}_{6}-\mathrm{Al}_{2} \mathrm{O}_{3}-\mathrm{MgF}_{2} "$, Electrochimica Acta, 38(15), (1993) 2165-2169.

[37]. P. Fellner, O. Kobbeltvedt, A. Sterten and J. Thonstad, "Electrical Conductivity of Molten Cryolite-Based Binary Mixtures Obtained with a Tube-Type Cell Made of Pyrolytic Boron Nitride", Electrochimica Acta, 38(4), (1993) 509-592.

[38]. Morigengaowa Bao, Zhao-Wen Wang, Bing-Liang Gao, Zhong-Ning Shi, Xian-Wei $\mathrm{Hu}$, Jiang- $\mathrm{Yu} \mathrm{Yu}$,"Electrical conductivity of $\mathrm{NaF}-\mathrm{AlF}_{3}-\mathrm{CaF}_{2}-\mathrm{Al}_{2} \mathrm{O}_{3}-\mathrm{ZrO}_{2}$ molten salts", Trans. Nonferrous Met. Soc. China, 23, (2013) 3788-3792.

[39]. E.J. Frazer and J. Thonstad, "Alumina Solubility and Diffusion Coefficient of the Dissolved Alumina Species in Low-Temperature Fluoride Electrolytes", Metallurgical and Materials Transactions B, vol. 41B, (2010) 543-548.

[40]. Alexander Silny, Marta Chrenkova, Vladimır Danek, Roman Vasiljev, Dang K. Nguyen and Jomar Thonstad, "Density, Viscosity, Surface Tension, and Interfacial Tension in the Systems $\mathrm{NaF}(\mathrm{KF})+\mathrm{AlF}_{3}$ ", J. Chem. Eng. Data, 49, (2004) 1542-1545.

[41]. Arthur W. Adamson, "Physical chemistry of surfaces", $3{ }^{\text {rd }}$ edition, Wiley $\square$ Interscience, New York, 1976, 698 p.

[42]. Xiaojun Lv, Zhenming Xu, Jie Li, Jiangan Chen, Qingsheng Liu, "Molecular dynamics investigation on structural and transport properties of $\mathrm{Na}_{3} \mathrm{AlF}_{6}-\mathrm{Al}_{2} \mathrm{O}_{3}$ molten salt", Journal of Molecular Liquids, 221, (2016) 26-32.

[43]. V.A. Kryukovsky, A.V. Frolov. O.Yu. Tkacheva, A.A. Redkin, Y.P. Zaikov, V.A. Khokhlov, A.P. Apisarov, "Electrical Conductivity of Low Melting Cryolite Melts", Light Metals, (2006) 409-413.

[44]. Qian Xu, Yiming Ma, and Zhuxian Qiu, "Calculation of Thermodynamic Properties of LiF-AIF $3, \mathrm{NaF}_{-} \mathrm{AIF}_{3}$ and KF-AIF 3 ", Calphad, 25(1), (2001) 31-42.

[45]. Galina Tsirlina, Evgeny Antipov, Dmitrii Glukhov, Alexander Gusev, Veronika Laurinavichute, Renat Nazmutdinov, Dmitry Simakov, Sergey Vassiliev, TamaraZinkicheva, "Specific Molecular Features of Potassium-Containing Cryolite Melts", Light Metals, (2012) 787-791.

[46]. Renat R. Nazmutdinov, Tamara T. Zinkicheva, Sergey Yu. Vassiliev, Dmitrii V. Glukhov, Galina A. Tsirlina, Michael Probst, "A spectroscopic and computational study of $\mathrm{Al}(\mathrm{III})$ complexes in cryolite melts: Effect of cation nature", Chemical Physics, 412, (2013) 22-29.

[47]. Jianhong Yang, Wangxing Li, Hengwei Yan, Dan Liu, "Conductivity of KF-NaF- $\mathrm{AlF}_{3}$ System Low-Temperature Electrolyte", Light Metals, (2013) 689-693. 
[48]. A. P. Apisarov, V. A. Kryukovskii, Yu. P. Zaikov, A. A. Red'kin, O. Yu. Tkacheva, and V. A. Khokhlov, "Conductivity of Low-Temperature $\mathrm{KF}-\mathrm{AlF}_{3}$ Electrolytes Containing Lithium Fluoride and Alumina", Russian Journal of Electrochemistry, 43(8), (2007) 870-874.

[49]. Zuzana Vaskova, Martin Kontrik, Jarmila Mlynarikova and Miroslav Boca, "Density of Low-Temperature $\mathrm{KF}-\mathrm{AlF}_{3}$ Aluminum Baths with $\mathrm{Al}_{2} \mathrm{O}_{3}$ and $\mathrm{AlPO}_{4}$ Additives", Metallurgical and Materials Transactions B, 46B, (2015) 485-493.

[50]. Alexander A. Redkin \& Elena V. Nikolaeva \& Alexander E. Dedyukhin \& Yurii P. Zaikov, "The electrical conductivity of chloride melts", Ionics, 18, (2012) 255-265.

[51]. N. Q. Minh, R. O. Loutfy, N. P. Yao, "The electrolysis of $\mathrm{Al}_{2} \mathrm{~S}_{3}$ in $\mathrm{AlCl}_{3}-\mathrm{MgCl}_{2}-$ $\mathrm{NaCl}$ - KCl melts", Journal of Applied Electrochemistry, 12, (1982) 653-658.

[52]. Hongwei Xie, Jinxia Wang, Yuchun Zhai, Xiaoyun Hu and Chengde Li, "Low-Melting $\mathrm{CaCl}_{2}-\mathrm{NaCl}-\mathrm{Al}_{2} \mathrm{O}_{3}$ Electrolyte for Direct Electrochemical Reduction Solid $\mathrm{Al}_{2} \mathrm{O}_{3}$ ", The Open Materials Science Journal, 5, (2011) 83-88.

[53]. Balaraju J. N, Ananth V, Sen U, "Studies on low temperature Al electrolysis using composite anodes in NaF-KCl bath electrolyte", J. Electrochem. Soc., 142, (1995) 439-444.

[54]. Theodore R. Beck, "Production of Aluminum with Low Temperature Fluoride Melts", Light Metals, (1994) 89-95.

[55]. U.S. Parent No. 4,592,812. T.R. Beck and R.J. Brooks, "Method and Apparatus for Electrolytic Reduction of Alumina", 1986.

[56]. U.S. Parent No. 4,865,701. T.R. Beck and R.J. Brooks, "Electrolytic Reduction of Alumina", 1989.

[57]. U.S. Parent No. 5,006,209. T.R. Beck and R.J. Brooks, "Electrolytic Reduction of Alumina", 1991.

[58]. Andrey S. Yasinskiy, Petr V. Polyakov, Yan V. Voyshel, Tatiana R. Gilmanshina \& Sai Krishna Padamata, "Sedimentation behavior of high-temperature concentrated colloidal suspension based on potassium cryolite", Journal of Dispersion Science and Technology, 2018, 13 January, DOI: 10.1080/01932691.2017.1421077. ( In press)

[59]. A.S. Yasinskiy, P.V. Polyakov, O.V. Yushkova, V.A. Sigov, "Spatial Particle Distribution during Stokes Sedimentation of Alumina in High Temperature Concentrated SuspensionElectrolyte for Aluminium Production, Tsvetnye Metally, 2018(2), (2018) 45-50. ( In Russian)

[60]. Kirpichev, M.V., Teoriya podobiya (Similarity Theory), Moscow: Akad. Nauk SSSR, 1953, 94 p. ( In Russian)

[61]. A. S. Yasinskiy, P. V. Polyakov, and A. B. Klyuchantsev, "Motion Dynamics of Anodic Gas in the Cryolite Melt-Alumina High-Temperature Slurry", Russian Journal of Non-Ferrous Metals, 58(2), (2017) 109-113.

[62]. J.C. Maxwell, A Treatise on Electricity and Magnetism, vol. 1, $3^{\text {rd }}$ edition, Clarendon, Oxford, (1904) 435-441.

[63]. Vogt, H., "Gas-evolving electrode", Comprehensive treatise of electrochemistry, NewYork-London: Plenum, 6, (1983) 445-489.

[64]. Sides, P.J., "Phenomena and effects of electrolytic gas evolution", Modern aspects of electrochemistry, New-York-London: Plenum, (18), (1986) 303-355.

[65]. Robinson C.D. Cruz, Jörg Reinshagen, Rainer Oberacker, Ana M. Segadães, Michael J. Hoffmann, "Electrical conductivity and stability of concentrated aqueous alumina suspensions", Journal of Colloid and Interface Science, 286, (2005) 579-588.

[66]. Christian Robelin, Patrice Chartrand, "A viscosity model for the $\left(\mathrm{NaF}+\mathrm{AlF}_{3}+\mathrm{CaF}_{2}+\right.$ $\mathrm{Al}_{2} \mathrm{O}_{3}$ ) electrolyte", J. Chem. Thermodynamics, 43, (2011) 764-774.

[67]. Alexander Kataev, Olga Tkacheva, Irina Zakiryanova, Alexey Apisarov ,Alexander Dedyukhin, Yuriy Zaikov, "Interaction of $\mathrm{B}_{2} \mathrm{O}_{3}$ with molten $\mathrm{KF}-\mathrm{AlF}_{3}$ and $\mathrm{KF}-\mathrm{NaF}-\mathrm{AlF}_{3}$ ", Journal of Molecular Liquids, 231, (2017) 149-153. 